\title{
Is exposure to biomass smoke really associated with COPD?
}

\section{Vandana Das \\ Vanjare Nitin \\ Sundeep Salvi \\ Rahul Kodgule}

Department of Pulmonary Function Laboratory, Chest Research

Foundation, Pune, Maharashtra, India

\author{
This article was published in the following Dove Press journal: \\ International Journal of COPD \\ 17 February 2017 \\ Number of times this article has been viewed
}

\section{Dear editor}

We read the article by Balcan et $\mathrm{al}^{1}$ with great interest. The authors have reported a case-control study that included 115 females and looked at the association between exposure to biomass smoke and detection of COPD. Although the authors concluded a positive association, we are concerned about the issues related to the conduct of the study and discrepancies in the data reported. COPD cases in this study were defined based on pre-bronchodilator forced expiratory volume in 1 second/forced vital capacity $\left(\mathrm{FEV}_{1} / \mathrm{FVC}\right)$ ratio $<0.70$. However, the Global Initiative for Chronic Obstructive Lung Disease (GOLD) guidelines define COPD based on post-bronchodilator $\mathrm{FEV}_{1} / \mathrm{FVC}$ ratio $<0.70$. Hence, many subjects detected to have COPD in this study may actually have had asthma, in which case, the findings of the study would not apply to the COPD population. Also the overall population included in the study was relatively younger (18-48 years). Use of a fixed ratio of $\mathrm{FEV}_{1} / \mathrm{FVC}$ is likely to lead to underdiagnosis of airflow limitation in this age group. ${ }^{2}$ Use of lower limits of normal would have been a better approach. Also, COPD is more common in age groups above 40 years. Therefore, we are not convinced about the selection of population with younger age.

The case definition was based entirely on spirometry which is susceptible to errors. Interpretation from 3 acceptable and 2 repeatable graphs ensures good-quality measurements. However, the authors did not report how the quality of spirometry was ensured and how many participants performed good-quality spirometry. ${ }^{3}$ It is difficult to believe that all $100 \%$ of the study participants performed good-quality spirometry.

The authors defined small airway disease as forced expiratory flow $25 \%-75 \%$ $\left(\mathrm{FEF}_{25 \%-75 \%}\right)<60 \%$ predicted. However, the values of $\mathrm{FEF}_{25 \%-75 \%}$ are also reduced in subjects with lower FVC. Hence, use of the ratio of $\mathrm{FEF}_{25 \%-75 \%}$ to FVC corrects for the effect of reduced FVC and provides more reliable information. ${ }^{4}$ Considering 20 cases with reduced FVC suggests significant confounding of the association with small airways disease due to reduced FVC.

We would also like to highlight the issues related to the statistical tests used and data reported. The authors have reported lung function data in median and inter-quartile range. The visual impression of Figure 3 suggests that the data were not normally distributed. However, the authors have compared the two groups (cases and controls) using the parametric $t$-test. A non-parametric test in this instance would have been more appropriate. The numbers reported in different tables did not match with each other. For example, the authors report 27 participants as having small airways disease in Table 3, whereas they report 17 participants as having small airways disease in Table 5. Also in Table 5 the authors have reported that 115 participants (95 without
Correspondence: Rahul Kodgule Chest Research Foundation, Marigold Complex, Kalyani Nagar, Pune 4II 014, Maharashtra, India Tel $+9|99214| 2644$

Fax +9| $202703537 \mid$

Email drrahul@crfindia.com
International Journal of COPD 2017:12 65I-653

(c) (1) (8) ( 2017 Das et al. This work is published and licensed by Dove Medical Press Limited. The full terms of this license are avalable at https.//www.dovepress.com/terms.php cc. hereby accept the Terms. Non-commercial uses of the work are permitted without any further permisision from Dove Medical Press Limited, provided the work is properly atributed. For permision for commercial use of this work, please see paragraphs 4.2 and 5 of our Terms (https://www.dovepress. com/terms.php). 
restriction and 20 with restriction) had $\mathrm{FEV}_{1} / \mathrm{FVC}>70 \%$ suggesting that no one had reduced ratio, which emphasizes that no one in the study group had COPD.

In view of the above limitations, we wish to alert the readers of the journal to interpret the results of this study cautiously.

\section{Disclosure}

The authors report no conflicts of interest in this communication.

\section{References}

1. Balcan B, Akan S, Ugurlu AO, Handemir BO, Ceyhan BB, Ozkaya S. Effects of biomass smoke on pulmonary functions: a case control study. Int J Chron Obstruct Pulmon Dis. 2016;11:1615-1622.

2. Cerveri I, Corsico AG, Accordini S, et al. What defines airflow obstruction in asthma? Eur Respir J. 2009;34(3):568-573.

3. Miller MR, Hankinson J, Brusasco V, et al; ATS/ERS Task Force. Standardisation of spirometry. Eur Respir J. 2005;26(2):319-338.

4. Litonjua AA, Sparrow D, Weiss ST. The FEF25-75/FVC ratio is associated with methacholine airway responsiveness. The normative aging study. Am J Respir Crit Care Med. 1999;159(5 Pt 1):1574-1579. 


\section{Authors' reply \\ Baran Balcan' \\ Selcuk Akan² \\ Aylin Ozsancak Ugurlu' \\ Bahar Ozcelik Handemir ${ }^{3}$ \\ Berrin Bagcı Ceyhan ${ }^{4}$ \\ Sevket Ozkaya ${ }^{5}$}

'Department of Pulmonary Medicine, Baskent University Faculty of Medicine, Istanbul, ${ }^{2}$ Department of Internal Medicine, Ankara Education and Teaching Hospital, Ankara, ${ }^{3}$ Department of Pulmonary Medicine, Irmet Hospital, Tekirdağ, ${ }^{4}$ Department of Pulmonary Medicine, Marmara University Faculty of Medicine, ${ }^{5}$ Department of Pulmonary Medicine, Faculty of Medicine, Bahçeșehir University, Istanbul, Turkey

Correspondence: Baran Balcan

Department of Pulmonary Medicine, Baskent University Faculty of Medicine, 7 Oymaci Street, Istanbul 34662, Turkey

Tel +905304l42308

Fax +902165541500

Email drbaranbalcan@yahoo.com

\section{Dear editor}

According to GOLD guidelines, post-bronchodilator pulmonary function test results are taken into account to diagnose COPD. As this is a standard criterion according to GOLD, we did not mention it in the methodology section, though we used post-bronchodilator results. Moreover, it is known that in a standard spirometry test, the best of three attempts should be taken into consideration; therefore, we did not mention that the best of three attempts was taken.

In addition we excluded allergic diseases such as asthma based on both the spirometry results and the past medical history of patients (patients who were diagnosed with asthma and allergic rhinitis were also excluded).

This study was performed in a territory that has poor environmental setting and technical supports. We evaluated the patients using simple pulmonary function tests. Advanced tests such as radiological imaging with chest X-ray or computed tomography should have been performed to attain accuracy, but we were lacking these types of supports.

\section{Disclosure}

The authors report no conflicts of interest in this communication.

Dove Medical Press encourages responsible, free and frank academic debate. The content of the International Journal of Chronic Obstructive Pulmonary Disease 'letters to the editor' section does not necessarily represent the views of Dove Medical Press, its officers, agents, employees, related entities or the International Journal of Chronic Obstructive Pulmonary Disease editors. While all reasonable steps have been taken to confirm the content of each letter, Dove Medical Press accepts no liability in respect of the content of any letter, nor is it responsible for the content and accuracy of any letter to the editor.

\section{Publish your work in this journal}

The International Journal of COPD is an international, peer-reviewed journal of therapeutics and pharmacology focusing on concise rapid reporting of clinical studies and reviews in COPD. Special focus is given to the pathophysiological processes underlying the disease, intervention programs, patient focused education, and self management protocols.

\section{Dovepress}

This journal is indexed on PubMed Central, MedLine and CAS. The manuscript management system is completely online and includes a very quick and fair peer-review system, which is all easy to use. Visit http://www.dovepress.com/testimonials.php to read real quotes from published authors. 